QIJIS: Qudus International Journal of Islamic Studies

Volume 5, Issue 2, August 2017

\title{
ISLAMIC EDUCATION UNIFYING NATION
}

\author{
Mukhamad Saekan \\ STAIN Kudus, Central Java, Indonesia \\ muhsaekan@gmail.com
}

\begin{abstract}
Islamic education for the nation of Indonesia becomes very important because it is known as a diverse nation in various aspects, such as religion, ethnic groups, languages, traditions and even colors. Once differences isnot supported by human maturity, it easily leads to conflict of life. Maturity becomes the main factor to set it in order, safe, comfortable and peaceful atmosphere among humans. Maturity is also one indicator of educational success. It is characterized by three things: independence, stability and responsibility. These three are able to realize personal quality and also produce the social quality for humans. Based on Law number 20 year 2003 about National Education System, the position of Islamic education is very strategic because its essence contained also functioned as barometer in arranging the Indonesia national education system. They are found out as the unity of the nation, among others, spiritual power, the ability of self-control, personality, intelligence, noble morals and various life skills that are useful for individual, society and country. Religion and education both teach peace, politeness, harmony and mutual cooperation, but what is taught by religion and education yet still far from expectation. Many Indonesians are in doubt about Pancasila, the national ideology. Some Moslems are still wrong in understanding
\end{abstract}


and practicing the value or value of Islamic teachings. The relations between groups, tribes, inter-religion areprone to conflict. Pancasilais created for the nation and state foundationis yet in debate and disputed. Tragically some of them urge to change Pancasila into an Islamic base, in their own perception. They insist that Islam shall apply Islamic law by enforcing Islamic state system (khilafah) to be applied in Indonesia. That way of thinking, may lead to a separation among Moslem once it does not tied to an Islamic education. Conflict can easily arise only because of different religions, beliefs, tribes, colors, languages, cultures, and temporary interest. Peace and the unity of Indonesian can be strengthened from the optimization of Islamic education process and implementation as its mission or content of Islamic education has a strong relevance toward the characteristics of the Indonesian nation.

Keywords: Education, Islamic Education, Indonesian Nation.

\section{A. Introduction}

Globalization era characterized by an open, democracy, information technology and borderless relationship between countries / nations thus create any change of nature and human character that was initially polite became rude, from humanist to materialistic, and which originally socialist become individualist. The changes have implications for the lack of brotherhood sense, believed triggering conflict among human being. Conflict could be acknowledged into a vertical such as inter-elite society, also horizontal, which is among common human being, fellow groups, and organizations within society.

Law No. 20 year 2003 about the national education system explains that education ideally has a very noble mission to develop the potential of human being such as religion and spiritual strength, self-control ability, personality, intelligence, noble morality and various useful life skills for himself, society and state (Article 1, paragraph 1).While education will be able to 
be the main pillar to conduct qualified human being both seen from physical aspect (born) and spiritual (inner).

Strong evidence that education will be able to produce qualified people can also be seen from the principle of education implementation which consists of: First, education is held democratically, justly and non-discriminatory by upholding human rights, religious values, cultural values and national pluralism; Second, education is organized as an entity with an open and multi-meaning system; Third, education is organized as a process of culture and empowerment of learners that lasts for life; Fourth, education is organized by giving exemplary to build willingness and develop creativity of learners in the learning process; Fifth, education is organized by developing culture to read, write and understand numeracy for all citizens; Sixth, education is organized by empowering all components of society through participation in the implementation and quality control of education services. (Chapter III, chapter 4, paragraph 1-6).

Many things required to realize the idealism of education in order bearing the figure of human personality. From the teacher's aspect, are also required to have various skills in doing learning tasks. Teachers are urged with various consequences both physical (physical) and spiritual (non-physical). Teachers have great strength from themselves (inner strength) that must be supported with good character related to personal and social.

Kath Paterson (2007: 21-24), explains that in order to achieve success, teacher must have several qualities: confidence, self-esteem, and social competence, hardness of heart, calm and firmness. These characters are expected to cultivate the attitude of human personality in building peace, comfort, harmony, peace between people without judging religion, tribe, class and color.

Many ways or learning models are expected to create character who's adjustably living the life of nation and state. One learning model is done by building comfort or pleasure in order to produce high motivation or strong suggestion from within. 
Learning model needs to be designed to support learners to achieve intelligence and also good skills related to intellectual intelligence (cognitive), intelligence of personality attitude (affective) and mechanical intelligence (psychomotor).

Bobbi DePorter \& Mike Hernacki (2006: 15-16), Quantum Learning is a way that combines sugestology, acceleration learning techniques with confidence that will configure a strong character and have survival strategy in facing the problematic life. Quantum learning is a learning meaninto a comfortable and enjoyable pattern, packed with attention to the characteristics and learners psychological condition so they may easily receiving the taught material. Calm, comfort and pleasant conditions are the determinants of educational and learning success. What is delivered will be easily understood, the value of education into a spirit or life system.

Educational practices do not always run smoothly, what idealized or dreamed is not fully made into reality. Education idealism as the root human character or personality, found that in the reality yet there many people with no character. Relations between people are not fully harmonized, religion that should be the basis of good attitude and behavior sometimes even misused as legitimacy of the bad behavior or violence. The relationship between parent and child should be a respectful even found into a hostile tight. Indonesia is supposed to be the country and nation where to look for beauty and comfort turned into an arena for violence and even war

Religion and education both teach peace, politeness, harmony and mutual cooperation, but what is taught by religion and education yet still far from expectation. Many Indonesians are in doubt about Pancasila, the national ideology. Some Moslems are still wrong in understanding and practicing the value or value of Islamic teachings. The relations between groups, tribes, interreligion are prone to conflict. Pancasila is created for the nation and state foundation is yet in debate and disputed. Tragically some of them urge to change Pancasila into an Islamic base, in 
their own perception. They insist that Islam shall apply Islamic law by enforcing Islamic state system (khilafah) to be applied in Indonesia.

Islamic education in Indonesia has at least two dimensions, religious and nationality. Religious dimension means education has duty and responsibility to give knowledge and understanding to human being to have a broad perspective on what Islam is and how to run the teaching of Islam as a whole and comprehensive.

The religious dimension in Islamic education gives awareness of how to perpetuate Islamic Sharia in a polite and peaceful way to manifest positive image of Islam in the eyes of any human religion, tribes and groups. Islam came and appeared to make friendly life atmosphere for all without seeing religion, tribe, and class and skin color.

The nationalism dimension in Islamic education are the duty and responsibility to provide knowledge, understanding and skills in life in accordance with national tradition. Islamic education for the Indonesian is its way of educating people in understanding Indonesia as "home". Islamic education in Indonesia should teach the importance of preserving the traditions or cultures. This is based on the assumption that Islam is a religion with very wide scope, not merely a ceremonial affair or worship, but does concern social and even politics. .

Based on that assumption, it can be concluded that Islamic education has a strong connection with the life of citizen in its way on strengthening the sense of nationalism embodied with the unity, among groups. Islamic education can be an example in guiding and fostering society upholding and practicing Pancasila in nation state living since Islam and Pancasila have nothing to contradict. Therefore, it is necessary to formulate how Islamic Education can actualize the unity of nation, by different religions, ethnic groups and skins (race) 


\section{B. Discussion}

Islam is a religion that Allah given to the chosen man teaching the importance of believing in God (monotheism/ tauhid), worshiping God (ibadah), social interaction between human (mu'amalah), politics, the importance of keeping the environment. Islam as a belief means"one" because Islam anywhere in the world stays the same, delivering the importance of good personal attitude (moral) in social life.

Ali Imran (2015: 427-429) explains that Islam brought into the world may always related to the phenomenon or reality of an occurred society's tradition calledjahiliyah. Jahiliyahby language means stupid. Stupid here does not mean as inability to read or write or no knowledge, but the lack of understanding to any religion or the way to have a good moral within social life. However, attitude and personality (morality) does not recognize space and time, meaning wherever Islam forbids it means also applies in all regions, such as stealing and lying. In Islam, punishment is applied like if a thief is caught will be punished (sanctioned) cut off his hand, the legal norm of cutting hands that exist in Islam Holy Book (Al Quran) and actually applies in all areas of this world.

Islam, understood in perspective is about how to get to know and practicing Islam that will be different according to the situation and conditions of the Moslem itself. In analogy, the way Indonesian Muslim understanding Islam will be different from Muslim in Middle East and India as the diversities of sociological societies significantly exist.

Moreover differences on Islamic thinking between Indonesia and non-Indonesian caused by the way Islam entering the territory. RizemAizid (2016: 33-39), explained that Islam entered Indonesia through several ways, through trade routes, marriage lines, social structure process, education, cultural arts and Sufism (tasawuf). All the way Islam widespread in Indonesia adapt to the characteristics of the Indonesian nation. There is no data that Islam came into Indonesia by violence or war. 
This also conveyed by AjidThohir (2009: 294), that Islam in Indonesia, especially in Java island, grown and spread out through adjusting onto the custom or Javanese culture. The da'wahof Islam inJava land gives a lot of concessions to the syncretic belief system where the Hindu-Buddhist teachings mixed with the original taught. It eases realizing Islamizationor at least reduces its difficulties.

From historical aspect, Indonesian Islam is seen by its entry way or da'wahmethod which always pay attention to the existing situation and tradition. Islam does not diminish anything or forbidding the running tradition. Indonesian Islam reinforces, develops and influences evolutively by not disturbing the psychology of the local community. While the current value of cultural or tradition values is maintained, Islam has grown in Indonesia.

To teach and giving an understanding of Islam to society shall be done by all ways that uphold values of humanity in both religion and nation state. Indonesia's character portraying on how society keeping its harmony, peaceful, cooperative, and rising mutual respect. By Bhineka Tunggal Ika, implicating that no reason to distinguish one another based on religion, tribe, class, or even color.

Islam in Indonesia compare to one in Middle East, Europe, America, Australia, or other Asia is that Indonesia's get closed to existing tradition and culture. Islam Indonesia came in while those traditions did existed, then Islam find the way to preserve not replace, although values of Islam were delivered, but more on emphasizing the substances not showing off its symbols or preaching Islam by specific movements.

\section{Islamic Education}

Islamic education is the character of education. Therefore, to understand the meaning of Islamic education is an apple to apple on understanding education itself. Generally, education means the process of developing potentials done by every human 
being with full consciousness and structured in order to make a change for the welfare of life. Based on Education System Constitution No 20. Year 2003, education defined as a conscious and planned effort to create learning atmosphere and learning process so that learners could actively develop their potentials in spiritual or religion, self-control, personality, intelligence, noble moral, and the necessary skills for himself, society, and nation state (Article 1 paragraph 1).

Arthur S Reber\& Emily S Reber (2010: 301), Education means pulling out, developing, and eliminating. Education also means the process of pulling thing out, building connection, especially things reflected on fundamental relationship of objects and phenomena. By this understanding, it defines Islamic Education as a conscious and planned effort to develop all potentials so that human being are aware about themselves, relationship among human (muamalah) and the relations with The Creator ('ubudiyah) in order to achieve prosperity in the world and hereafter (akheerah).

The essence of Islamic Education lies in its ability to build consciousness to know and understand who he really is, how to interact with neighbor and environment also how to communicate with The Creator (Allah SWT). The process of building comprehensive and qualified awareness are based on ratio and Islamic norms that been written in Qur'an, Hadith, Ijma', Qiyasalso scientific opinion of competent expert and scholars. Islamic education means the process of thinking and activity based on awareness of The Creator (Allah) realizing the balance of minds and norms of Islamic teaching (Al Qur'an and Hadith).

The significance of using mind and consciousness of The Creator can be seen in the Surah Al Alaq verse 1-5 "Recite in the name of Your Lord Who created. Created man from a clot of congealed blood. Recite: and your Lord is most generous. Who taught by the pen. Taught man what he did not know." The verses teach us that in every reading (activity) shall always remembering the existence of Allah, The Almighty who created human and 
gave knowledge so that human are able to do anything correctly as suitable to social and religious norms. The main purpose of Islamic education is to make people aware of themselves and to behave to God and environment correctly as a manifest for prosperity in the world and after life. There some scholars with different perspective about Islamic education:

Naquib Al Attas (1979: 14) thepurspose of Islamic education should be based on human life philosophy. Islamic Education aimed to create a perfect man (InsanKamil) whose qualified in speech, mind, heart feeling, and the way he behave or his action.

Muhammad Athiyah Al Abrosyi(1975: 22-25), Islamic education goal is to prepare human being in facing life in the world and after life, prepare them on the way find a good earning and livelihood, also on preserving good attitudes (noble behavior), fostering the spirit to studying sciences, and get the ready to be professionals.

AbdarRahmananNahlawi (1992: 162), Islamic education aims to develop thoughts, behaviors and feeling to lead the obedience to Allah SWT within human life both for individual interest or social life. AbdarRahmanNahlawi convinces an understanding of consciousness of human to get to know more on the nature of human being and also about God, Allah SWT. The ultimate goal of Islamic education put into the order of life good system,courteousness, peace, and mutual respect.

Islamic education is identified from three perspective points. First, the institutional or formal, that process of education uses symbol or specific name, such as Elementary School (SekolahDasar/SD) Islam, Islamic Junior High School (SMP) Islam, High School (SMA) Islam, Vocational High School (SMK) Islam or any other name mentioning clearly term of Islam such as Madrasah Ibtidaiyah, Madrasah Tsanawiyah, Madrasah Aliyah or an institution for a boarding school purpose like PondokPesantren, or Taman Pendidikan Qur'an, and Madrasah Diniyah. 
Second, the subjects' perspective. Islamic education is an education process that teaches basic material of Islam religion, such as fiqh, aqidah, akhlaq, history of Islamic culture, tafsir, Al Qur'an, hadith, tasawuf, and subjects related to Islamic education.

Third, the emphasizing material perspective. Islamic education has three material parts, they are Tarbiyah, Ta'lim, danTa'dib. Tarbiyahrefers to quality of intelligence/ cognitive skills, an understanding to knowledge, application, analysis, synthesis and evaluation. It is spoken that anyone having cognitive intelligence only if he master on the six stages are been passed. Ta'lim, focus on social ethics within the process of education or learning, among students, or student to teacher. It concern on how student behave to teacher and to other fellow students in learning process. Education with the word ta'limemphasize on the importance of ethics, social attitudes, manners and personality, especially focus on how they behave to teachers. In this modern era, human demand on an open and freedom set which implicate to the degradation of ethic among students and worsen to the teachers. Several cases reported that students sue their teacher by criminal allegation caused by simple thing. Thus, it takes teacher to be careless to students because they feel unsecured anytime student can put them in jail by his little wrong doing.

Ta'dibexplaining the existence of awareness to get to know, believe and understand God's position. The word ta'dibput education as how students having knowledge, understand and aware about God's position to man, to His creation. Human should understand that everything done is seen by God, even only a feeling inside his mind. This may implicate to the student's spiritual intelligence or in other way they have the skill to apply the religious values into the system of life.

Ideally, education has a noble goal as its predicted that Islamic education can create quality of people with a complex skills to survive facing problems in social life. Why so? Islamic education trains and lead people to be ready to live in the world 
and hereafter, hence being a proper profile like what said in Quran;

"Rabbana atina fil duniya hasanah, wafi al akherati hasanah, waqina adzaba al naar."

Islamic education already occurred since Prophet Muhammad received his revelation that was surah Al Alaq 1-5 "Recite in the name of your Lord who created. Created man from clinging substance. Recite, and your Lord is the most Generous. Who taught by the pen. Taught man that which he knew not." Also surah Al Mudatsir 1-7 "O you who covers himself [with a garment]. Arise and warn. And your Lord glorify. And your clothing purify. And uncleanliness avoid. And do not confer favor to acquire more. But for your Lord be patient"

Those two verses believed as starting point of the birth of Islamic Education, started since Rasulullah, Prophet Muhammad SAW teaches the importance of building attitude and moral of human being whereas should keep the cleanliness in tangible ways, such clothing, body, and also the intangible parts such hearts and however human being is suggested to not doing anything forbidden ( $\sin$ ) and how every human have to be patient in dealing with all issues of personal or social life.

\section{Islamic Education Unifying Nation}

Indonesia as a nation is easily acknowledged by the relations among human, between elements or groups which somewhat lead to conflict or contradiction. Not to mention, the conflict is triggered by simple thing, inessential one. Conflict between groups is caused by misunderstanding, feeling offended and humiliated. Indonesia as a peace lover nation, prefer to live in harmony, exaggerating the sense of helping each other is rarely found today. Moreover, the relationship between student and teacher, or between young to parents which was used to uphold ethic is getting distinct, while the nation is seen rude, rough and a bit arrogant or AndapAsor, Javanese tradition in keeping a descent manner or attitude of young to elders hardly seen 
today. Nevertheless, Indonesia shall be back to those ideas, as a nation with high human civilization, and this is very essential. Generations, students should learn to develop knowledge, manners, and ethics, have such a good personality to eradicate conflict, brawl among students. This is true that Islamic education is essentially have a firm purpose emphasizing on humanity, appears as a solution answering various questions and problems both related to personal or social and transcendental.

\section{a. The nature of Islamic Education}

The author has clearly stated that essentially Islamic education build or fostering human consciousness to develop all potentials manifest for the prosperity in the world and hereafter (akreerah). Psychological Dictionary by Arthur S Reber\& Emily s Reber explains that the word "consciousness" means as the condition of awake or alertness or mental aspect with wholly awake from danger or possible bad things. The word consciousness alter to "self-conscious" which means of the shy feeling or uncomfortable for doing anything contrary to track or what supposed to be done.Safrudin Aziz (2015: 18-24), explains that Islamic education generally has two objects or studies, namely the individual aspect which associated to God (Tauhid) and social aspect related other human and environment (Mu'amalah). Both objects have been exemplified by Prophet Muhammad during Mecca and Medina period. Within those periods Islamic education tend to put human understanding themselves, their nature about how they are made into the world, about who creates them to produce a noble attitude in social life. Each human need to aware about his origin, what he is made of, from something apart from beautiful or honored, but from thing people see it disgusting. As stated in Qur'an surah Al Mu'minun verse 12-14 "And certainly did We created man from an extract of clay. We placed him as a spermdrop in a firm lodging. We made the sperm-drop into a clinging clot, and We made the clot into a lump [of flesh], and We made [from] the lump, bones, and We covered the bones with flesh; then We 
developed him into another creation. So blessed is Allah, the best of creators."

The awareness on human nature may produce a noble soul, whether no arrogance, jealousy to others, and a soul that been patient in facing reality in life. This type of consciousness is necessitate to build sense of unity among human being. Islamic education also emphasizes the importance of having good communication and interaction among human being and its capability to manage and empower the present potentials beyond themselves. Islamic education in Medina period signifies that human being should be able to set up a convenience living system for all, such build up economic system, politics, manifest on natural environment and also an ethic of nurturing animals. Thus, actually Islamic education has a wide and comprehensive scope and very effective in building human character in its way creating a safe, peaceful, happy, and prosperous life system.

\section{b. Characteristic of Islamic Education as Science}

The characteristic may be different from a non-Islam science. Islamic education character is related to matter beyond the science itself, while what non-Islamic (general) education merely focus on anything inside the science. In example, a natural science materials or mathematic provide an understanding about the science, describing it but there is no space which accommodate student to understand what the correlation of one subject to another subject. On the other hand, in Fiqh, Al Quran or Tafsir, students are brought to know beyond the Fiqhsubject or Tafsir, such as sociology, psychology, anthropology. In fiqh even discuss about inheritance (property) science (Mawaris), while student also need to learn about calculation inside. In studying Al Quran or Tafsir, this is necessary to understand AsbabunNuzulAyat, which means that everyone who studies the science of Quran or Tafsir should understanding psychology and sociology. Another case is Moslems know about the subject of Fiqh specifically in the chapter of Sholat(prayer) and find the term Khusyu' (solemn) 
they will understand it as whole once they also understand about psychology.

It shows that Islamic taught characteristic are quite far from what taught by general knowledge or non-Islam. It also can be understood that Islamic education character is "multiinteractive", that there always a connection and interaction to one another, matter outside of the basic science itself, while the general knowledge (Non Islamic Education) get focus on learning the science or named "mono-interactive", that only in thing focused is the science itself, no more.

The cross-sectorial or multi-interactive of science lead human character, the Islamic Education learners to be a great soul one, granted with knowledge and understand on disciplines and to be an insightful one and ready to face various problems of differences in the reality of life. Moreover, Islamic education tend to give a wide and open approach as a principal of solving problems.

\section{c. Islamic Education and Medina Charter}

This is surely that history fact and past phenomenon shall be put on the basis on the way building unity and national integrity, while in Islamic history called as Medina Charter, First Constitution. Here is a manuscript of an agreement between citizen with different religion, tribes and groups who agreed to build such a safe, comfortable, peaceful, and prosperous living system. Medina Charter is written agreement of the stakeholders to Medina people which consist of groups; Quraisy, Yasrib, and people who fought with them. ZainalAbidin (2014: 25-32) explains that Medina Charter consist of 10 chapters, and 47 articles containing the rights to live altogether, rights to exercise each religion based on their belief, rights to be united, by different religion, tribe, class, and mutually oblige to protect minority groups. It also stated about the importance of perpetuating peace of state and also politics. Medina Charter has a meaning of education among others, such as every person should mutually respect and appreciate one another in spite of religion. Tribe, group, which also means that there is an equality and exercising 
egalitarian. Second, each person have to perform their duties and function in social optimally. Groups shall not triggering conflict or taking other rights. Third, the idea of a leader should be a noble example (Uswah) for the followers. In education, a teacher should be able to be an example for his students. Islamic Education upholds the rights and obligation in balance, paying attention to the developing of human potentials to live optimally in accordance to religious and social norms. A condition indicating people live in civilized and cultured structure is while they are able to live side by side with society without taking it personal about the diversities of religions, tribes, and groups. Medina Charter is related tough to the mission of Islamic education which upholding the differences in order realizing togetherness. For Indonesia, Medina Charter is relevant to be understood because Indonesian are plural, diverse in term of religion, ethnic, language and colors.

\section{Conclusion}

Substantively, Islamic Education have sufficient material and scope which very relevant to build national integrity especially for Indonesia, nation with diverse religion, culture, tribe, language even color. In epistemology perspective, Islamic education is most suitable mean for unifying nation, because education always based on two things, they are the existence of The Creator and for sure human ratio. Both are needed to bring out awareness on human nature and for what human are finally created then how human should act and behave. Islamic education in science characteristic is known where education requires to have a broad, cross-sector, contextual, to whom studying Islamic education will have wide and broad perspective, understanding cross science, ideology, tradition to ease the acceptance of differences occurred within society. People with this capability will be able to understand and interpret all phenomena and fact in social life wisely.Medina Charter has strong relevance to Islamic Education thus it strengthening the Islamic education itself to be the mean for unifying nations. Medina Charter and Indonesia have a tight similarity seen from the diversities factor. 


\section{REFERENCES}

Ajid Thohir 2009, Perkembangan Peradaban di Kawasan Dunia Islam, Rajawali Press, Jakarta.

Arthue S Reber\& Emily S Reber2010, Kamus Psikologi, (terj), from the origin title :The Penguin Dictionary of Psychology, Pustaka Pelajar Jakarta.

Bobbi DePorter\& Mike Hernacki (terj) 2006, Quantum Learning: Membiasakan Belajar Nyaman dan Menyenangkan, XXIII printed, penerbit. PT Mizan Pustaka, Bandung Jawa Barat.

Kath Paterson 2007, 55 Teaching Dilemmas: 55 dilema dalam pengajaran, sepuluh solusi terpilih untuk menjawab tantangan dikelas, Grasindo, PT. Gramedia Widiasarana Indonesia, Jakarta.

Indonesia Constitution No 20 year 2003 about National Education System

M. Ali Imran 2015, Sejarah Terlangkap Agama Agama di Dunia, dari masa klasik hingga moderen, Ercisod, Yogyakarta.

Naquib Al Attas 1979, Aims and Objectives of Islamic Education, King Abdul Azis University, Jeddah Saudi Arabia.

Muhamamd Athiyah Al Abrosyi 1975, at Tarbiyah al Islamiyah wa Falasifatuha, Isa al Bab al Halabi, Kairo, Mesir.

Rizem Aizid 2016, Sejarah Islam Nusantara: from Analaisis historis arkeologis tentang Penyebaran Islam di Nusantara, Diva Press, Yogyakarta.

Safrudin Aziz 2015, Pemikiran Pendidikann Islam, Kajian Tokoh Klasik dan Kontemporer, Kalimedia, Yogyakarta.

Zainal Abidin Ahmad 2014, Piagam Madinah Konstitusi Tertulis Pertama di Dunia, Pustaka Al Kautsar, Jakarta 